\title{
이집트 국별지원전략 및 지원사업 종합평가
}

\author{
한국국제협력단1)
}

\section{목차}

I. 평가 개요

II. 이집트의 개발 환경과 대 이집트 무상원조

III. 대 이집트 국가지원전략 및 사업 평가

IV. 결론 및 건의

\section{I. 평가 개요}

ㅁ 이집트는 아프리카 지역 국가 중에서 가장 중요한 비중을 차지하는 협력대상국의 하나로 협력 사 업 규모와 영역이 꾸준히 확대되어 왔으며, 그간 대 이집트 사업 전반에 관한 종합적인 평가가 필 요한 시점임.

ㅁ 이집트에 대한 무상원조사업은 2006년 “아프리카개발을 위한 한국의 이니셔티브" 발표 이후 확대 되기 시작하였으며, 2007년 “대 이집트 국가지원전략(Country Assistance Strategy for Egypt 2008-2010: CAS'2)"의 수립을 통해 보다 체계적으로 추진되고 있음.

ㅁ 그 간에 실시된 다양한 사업의 성과와 문제점을 파악하고 $\mathrm{CAS}$ 의 수립과 활용에 대한 사항을 평가 하여 급속히 변화하고 있는 대 이집트 개발 환경과 여건에 효과적으로 대처하는 한편, 사업 추진 의 효과성을 높여나가기 위한 노력이 긴요한 상황임.

ㅁ 한국개발전략연구소는 한국국제협력단(KOICA)으로부터 위탁받은 "이집트 국가지원전략 및 지원 사업 평가" 과제의 수행을 위한 평가단을 구성하여 2010년 6월부터 구체적인 평가 방법 및 기법 의 개발, 평가 실시 매트릭스의 수립 등과 함께 문헌조사 및 국내조사를 시작으로 이집트 현지조 사 등을 실시하여 단계적인 평가 작업을 진행하였음.

1) $\mathrm{KOICA}$ 사업평가실 평가과제로 한국개발전략연구소가 수행함.

2) 2011년도부터 CPS로 바뀌었음. 
ㅁ 평가단은 $\mathrm{KOICA}$ 의 평가 지침과 $\mathrm{OECD} / \mathrm{DAC}$ 의 평가원칙 등에 입각하여 1) 대 이집트 국가지원전 략, 2) 대 이집트 원조사업 시스템 및 프로세스, 3) 대 이집트 개발협력 사업 등 3개 분야에 대한 평가를 실시하였음.

ㅁ 본 연구에서는 문헌조사, 국내조사, 설문조사, 기관방문, 현장조사 등의 다양한 방법을 통하여 대 이집트 지원사업에 대한 평가를 수행하였으며, 그 결과로서 전반적인 평가가 매우 긍정적으로 나 타났음.

○ 특히, 대 이집트 지원사업의 효과성 및 효율성이 매우 높은 것으로 평가되었음.

ㅁ 평가팀 구성

〈표1〉이집트 국별 평가 연구진 구성

\begin{tabular}{c|l}
\hline 구 분 & \multicolumn{1}{c}{ 담 당 } \\
\hline \multirow{4}{*}{ 국내 연구진 } & 이경구 상무이사 (한국개발전략연구소) \\
\cline { 2 - 2 } & 김종수 연구위원 (한국국제개발협력센터) \\
\cline { 2 - 2 } & 배성일 연구위원 (한국개발전략연구소) \\
\cline { 2 - 2 } & 이효경 기획관 (한국개발전략연구소) \\
\hline \multirow{2}{*}{ 현지 연구진 } & Zeinab Shahin \\
\cline { 2 - 2 } & Dina Wafa \\
\hline
\end{tabular}

\section{II. 이집트의 개발 환경과 대 이집트 무상원조}

ㅁ 이집트는 무바라크 대통령의 장기 집권 하에서 비교적 안정된 정치체제를 바탕으로 경제 - 사회적 인 안정과 성장을 도모해나가고 있음.

ㅁ 2000년 이후 지속적인 경제성장의 결과 국가의 경제적 지위를 저소득국(LIC)으로부터 중저소득국 (LMIC)의 수준으로 향상시켰으며 보다 적극적인 국가발전 전략 및 개발 계획을 시행해나가고 있음

○ 2007년 1월 “국가발전 장기비전 수립(A Future Vision of Egypt 2030: The General Framework)"의 수립 및 제시.

○ 2007/2008년부터 “제6차 5개년 계획(The 6th Five-Year Plan 2007/2008 -2010/2011)” 을 수립하여 시행 중.

ㅁ 이집트는 중저소득국으로 도약함에 따라 국민소득 수준이 제고되고 국가적 경제 역량이 향상되고 있으나 여전히 극복해야할 여러 가지 개발 과제를 안고 있음.

○ 급격히 늘어나는 취업인구의 고용기회 확대, 광범위한 빈곤의 완화, 소득계층간의 심각한 소득 
불균형 및 지역 간 개발 격차 해소, 행정 역량의 강화 및 효율성 제고, 취약한 재정 기반 건전화 및 구조개선 등.

○ 또한 향후 지속가능한 개발 역량을 위축시킬 수 있는 수자원 부족현상의 심화, 채취가능 자원의 고갈, 기후변화에 따르는 환경 악화 등의 문제점에 직면해 있음.

ㅁ 따라서 이집트 정부는 향후 보다 적극적인 국가개발 계획의 수립 추진을 계획하고 있으며, 이집트 개발에서 높은 비중을 차지하고 있는 대외원조의 효과적인 활용에 고심하고 있음.

○ 기존의 개발 계획과 원조사업 추진의 실효성에 대한 문제의식을 가지고 새로운 맥락에서 국가발전 비전 및 개발 계획을 재검토하고 이를 전략적인 관점에서 보완하기 위한 작업을 진행 중에 있음.

이이집트 정부는 2009년 12월 “정부의 8대 전략 목표(Eight Strategic Objectives of Government)" 를 새로이 설정하는 한편 특별작업반을 구성하여 개발원조사업의 효과적인 추진을 위한 "카이로 행동 계획(Cairo Agenda for Action: CAA)"을 마련 중에 있음.

ㅁ 우리나라는 그 간 이집트를 무상원조 중점협력 대상국의 하나로 선정하여 프로젝트, 개발조사, 연 수생초청, 봉사단파견 등 주요 협력 수단을 활용하여 다양한 사업을 전개하여 왔으며, 2007년 $\mathrm{CAS}$ 를 수립하여 보다 체계적인 지원사업의 추진을 도모해 나왔음.

○ CAS는 빈곤퇴치 지원과 지속가능 개발의 촉진이라는 기본적인 원조 지원 목적의 달성을 위하 여 (1) 인적자원개발, (2) 정보통신, (3) 환경, (4) 행정제도와 같은 4 개의 중점 분야에 대한 지원 을 집중적으로 실시해 오고 있음.

ㅁ 우리나라의 대 이집트 원조사업은 규모 면에서 지속적으로 증가해 왔을 뿐 아니라 기존 사업의 성 과도 성공적으로 평가되어 이집트에서는 우리나라에 향후 더욱 큰 규모의 지원을 기대하고 있는 것으로 파악되었음.

\section{III. 대 이집트 국가지원전략 및 사업 평가}

\section{가. 대 이집트 국가지원전략 평가}

\section{1) 전략 수립체계, 수립절차 등의 적절성}

ㅁ 적절한 원조전략 수립 체제하에서 "대 이집트 국가지원전략(CAS)"이 수립됨.

ㅇ “공적개발원조(ODA) 중기전략 2008-2010” 및 “대외무상원조 중기전략 2008-2010”과 그 궤 를 같이하는 체계 속에서 $\mathrm{CAS}$ 가 수립됨.

○ 2006년에 발표된 “아프리카 개발을 위한 한국의 이니셔티브" 발표 등 사업의 확대 - 발전 필요 성이 부각되는 적절한 시기에 전략을 수립함. 
"대 이집트 국가지원전략(CAS)" 은 처음으로 시도된 제 1 세대 CAS로서 정교한 내용의 전략 수립 절차 및 방법론 등이 구체적으로 체계화되기 어려운 상황에서 기본적인 협력 방향과 중점 등을 제 시하는 유도적인 성격의 전략으로 마련되었음.

○ 제 1 세대 $\mathrm{CAS}$ 수립 경험과 활용 성과 등을 토대로 $\mathrm{CAS}$ 수립 전반에 대한 절차와 방식을 점차 발전시켜나갈 필요가 있음.

\section{2) 지원전략 내용의 적절성}

ㅁ (원조목표, 중점지원 분야) 매우 뚜렷한 원조 기본 목표를 제시하고 있으며, 가용한 원조재원의 규 모를 감안시 그 대상이 폭넓게 설정되어 있는 것으로 나타났으나 그 중점지원 목표 분야와 중점 지원 분야는 매우 명확하게 설정되어 있음.

ㅁ (사업추진 계획의 구체성) $\mathrm{CAS}$ 는 유도적인 성격의 내용으로 거시적인 측면의 사업추진 계획에는 적합하나 미시적인 연도별 사업 실시계획을 수립하여 추진하기 위해서는 개선이 필요함.

○ 단년도 예산운영 방식으로 인하여 CAS를 통해 기간 중 투입 가능한 재원 규모의 제시 및 구체 적 지원사업의 적시 등이 곤란한 실정임.

○ 현재의 사업운영 시스템 하에서는 CAS가 시행되는 수년간의 연동화된 연차별 사업추진 계획, 재원 투입 파이프라인 등과 같은 개념의 계획 요소를 CAS에 구체화하기가 곤란함.

ㅁ (개발 및 성과 - 평가 지표 설정의 적절성) 유도적인 개발전략으로서 중기적인 사업 추진 기본 방 향 및 중점적인 지원 분야의 제시를 지원전략의 핵심으로 하고 있으며 개발 사업 관련 목표 지표, 사업성과 및 평가와 관련한 지표 등은 제시하지 않고 있음.

ㅁ (원조 방식 및 실시 기법) 대부분의 사업이 중소규모의 개별적인 기술협력, 또는 독립적인 프로젝 트형 사업으로 추진되고 있음.

○ 전체적인 사업 규모가 아직은 작은 수준일 뿐만이 아니라 사업 수행 편제가 국가 또는 지역에 초점을 둔 방향으로 이루어져 있지 않아 중점 지원 분야에 대한 개별적인 사업 추진 방식으로 사업이 이루어지고 있음.

○ 다만 인적자원개발 지원을 목표로 자동차 정비 직업훈련 분야에 대한 집중적인 지원이 이루어 지는 과정에서 결과적으로 개별 원조공여자에 의한 프로그램 접근 방식의 사업 실시가 이루어 지는 성과를 거두고 있음.

ㅁ (상위정책 및 전략과의 연계성) 앞서 수립된 “공적개발원조 중기전략” 및 “대외무상원조 중기전략" 의 목표 및 방향과 일치됨.

\section{3) 수원국 개발 전략 및 수용에의 부합성}

ㅁ (이집트 개발 환경과 특수 여건의 고려) 이집트 개발 환경에 대한 검토는 이집트의 빈곤 상황에 
대한 분석 및 6 차 5 개년 개발계획을 중심으로 하는 검토가 충분히 이루어졌으나, 중 - 장기적인 관점에서 이집트 발전 단계의 변화 및 대내외적 기본 여건의 변화 등에 대한 거시적인 검토는 $\mathrm{CAS}$ 수립과정에서 특별히 반영되지 않았음.

○ 중저소득국으로 향상된 이집트의 경제적 수준 변화, 저소득국 및 사하라이남 아프리카 지역에 대한 협력 강화 등 우리의 원조 정책 방향의 변화 등을 감안하여 향후 우리의 대 이집트 원조의 방향을 어떻게 설정할 것인지 등에 대한 거시적인 검토가 필요함.

ㅁ (국가 발전 비전과 개발 전략) 이집트에 대한 무상원조 지원전략은 이집트의 장기 국가발전 비전 및 중기 개발계획에 전적으로 부합하는 것으로 평가됨.

ㅁ (개발지원 수요의 충족) 이집트의 중 - 장기 재정 개발투자 계획은 대외 원조자금의 지원에 크게 의존하고 있으며, 그 간 $\mathrm{KOICA}$ 무상원조사업의 높은 성과에 따라 이집트 측에서 원조 규모의 적 극 확대를 기대하고 있음.

\section{4) 여타 개발협력 파트너와의 원조 조화}

ㅁ (유상원조사업과의 조화) 이집트에 대해서는 아직 유상 개발차관 사업을 제공하지 않고 있음.

ㅁ (여타 원조 공여국과의 조화) $\mathrm{KOICA}$ 이집트 사무소는 현재 41 개의 원조 공여기관으로 구성된 개 발파트너그룹(DPG)의 원조조화 활동에는 참여하고 있으나, 구체적인 원조사업 시행을 협의하기 위하여 19 개 주요 원조공여기관이 참여하고 있는 “Matrix on Donor's Intervention” 수립 과정 에는 참여하지 않고 있음.

\section{5) 국제원조규범에의 부응성}

ㅁ (MDGs 개발 목표 달성에의 기여) MDGs 개발 목표 달성에 대한 우리 무상원조사업의 직접적인 기여는, 8 개의 주요 MDGs 목표 중에서 제 1 의 '극심한 빈곤의 완화'와 제 7 의 목표인 '환경의 지속 가능성 확보' 분야에서 이루어지고 있는 것으로 평가되었음.

ㅁ (파리선언/아크라행동계획 이행) 본 연구의 설문조사와 2008년에 OECD/DAC가 실시한 파리선언 이행에 대한 조사결과를 비교해보면, 이집트에 대한 우리나라 원조사업의 이행 상황이 평가 항목 에 따라 약간의 차이가 있는 것으로 나타났음.

$\mathrm{O} \mathrm{OECD} / \mathrm{DAC}$ 의 조사결과에서는 국가 프로그램과 조화된 기술협력의 실시, 예측 가능한 원조 공 여 등의 항목에서 좋은 이행 성과를 나타냈으나, 국가시스템의 활용, PBAs 방식의 원조 실시, 공동조사 및 분석 활동 실시 등의 항목에서는 그 성과가 낮은 것으로 나타났음.

$\bigcirc$ 본 연구의 설문조사에서는 우리 원조의 예측 가능성이 상대적으로 낮은 것으로 평가되었음. 


\section{나. 원조사업 시스템 및 프로세스 평가}

\section{1) 사업실시 기본체계 및 사이클}

$\mathrm{KOICA}$ 의 현행 원조사업 시스템 상 분야별 중심 편제에서는 국가별 사업실시 체계 수립이 여러 부서로 분산, 다기화되어 있어서 $\mathrm{CAS}$ 를 기반으로 하는 사업수행 시스템 및 프로세스의 구축이 어 려운 것으로 파악됨.

ㅁ 주요 사업이 프로젝트형 사업, 연수생초청 사업, 봉사단파견 사업 등 유형별로 구성되었으며, 이에 대한 사업실시 사이클 및 추진 절차가 매우 합리적이고 정교하게 수립되어 적절히 운영되고 있음.

ㅁ 이집트라는 특정 국가를 대상으로 하는 전반적인 사업실시 계획의 마련에 있어서 국가 지향의 연 도별 사업시행계획 수립 절차 및 방법론이 마련될 필요가 있음.

○ 현재 사업 실시 과정에서 활용되고 있는 사업 수단 간의 연계 도모(프로젝트 사업의 사후관리측 면에서 봉사단파견 등)는 봉사사업, 연수사업 등의 사업 수단을 포함하여 이집트에 대한 연간사 업계획 수립 과정을 통하여 제도화되는 것이 바람직함.

ㅁ 글로벌 ODA 전문기관으로 도약 및 국가별 사업실시 체계를 뚜렷하게 수립하기 위해서는 수원국 의 국가개발전략에 더욱 초점을 맞추어 협력사업을 수행해나갈 수 있는 지역 편제 도입 등의 제도 개선이 필요하며, 이를 효율적으로 운용해 나갈 수 있는 적정 인력의 보강이 긴요함.

\section{2) 사업지원 프로세스}

\section{가) 기초조사 연구개발, 원조실시 기법 및 방법론}

$\mathrm{KOICA}$ 의 원조사업은 사업 효과 및 효율성 측면에서 그간 꾸준히 제도 개선이 이루어졌으나 이집 트를 포함하는 주요 협력대상 국가에 대한 기초적인 연구개발이 아직은 활성화되지 않고 있는 것 으로 평가됨.

ㅁ 국가 및 지역에 관한 기초조사 연구를 활성화하기 위한 제도적인 여건이 미흡하여 전문성과 일관 성을 갖춘 원조실시 기법 및 방법론 개발이 어려운 실정임.

ㅁ 국가 및 지역에 대한 기초 연구, 선진 원조기법 도입 및 원조실시 방법론 개발 등을 위하여 정책 연구실 등이 싱크탱크로서의 역량 강화를 위한 방안 마련이 필요함.

\section{나) 사업 발굴 및 형성, 사업실시 준비 등}

ㅁ 유망한 사업 발굴 및 형성 여건을 조성하기 위하여 수원 환경에 대한 신뢰할 만한 정보 입수 등이 필요하므로 수원국과의 정례적인 정책대화 및 전략적인 사업실시 협의체계를 구축하는 것이 필요함.

ㅁ 수요조사는 수원 창구를 통해 적절한 절차로 실시되고 있으며 원조효과가 높은 유망한 사업을 발 굴하기 위한 노력이 시도되고 있음. 
ㅁ 사업실시 준비를 위한 사업타당성조사, 사업 프로그래밍 및 설계, 사업실시 협의, 사업자 선정 등 의 절차와 방식이 적절하게 수립되어 있으며 전문성 있는 체제를 구축하여 운영되고 있음.

ㅁ 사업시행 및 모니터링은 현행 분야 중심의 시스템, 본부 및 현지 사무소의 인력 부족 등으로 체계 적이며 효율적인 실시가 어려운 것으로 평가되었음.

\section{다) 사업평가 및 사후관리}

ㅁ 원조사업 초기에는 프로젝트 사업 평가의 중요성 인식 부족 등으로 사업 중간 평가 등이 실시되지 않은 사례가 발견되었으나, 사업 규모가 커지고 사업 평가에 대한 지침이 강화되면서 크게 개선되 는 추세를 보이고 있음.

ㅁ 종료사업에 대한 사후 관리는 프로젝트사업 사후관리지침에 따라 적절히 이루어지고 있으나, 보다 면밀한 사후관리 모니터링 시스템을 구축하여 운영할 필요가 있음.

○ “자동차 정비 직업훈련원 지원 사업”의 경우, 기 실시 사업에 대한 역량강화 사업의 일환으로 체계적인 사후관리를 제공하는 것은 바람직한 사후관리 기법으로 여타 사업에도 적극 활용하는 것이 바람직함.

\section{다. 대 이집트 지원사업 평가}

\section{1) 프로젝트형 사업}

ㅁ 1991년부터 이집트에 지원된 주요 개발조사/프로젝트 사업은 5 개 분야(교육, 산업에너지, 정보통 신, 농어촌개발 및 환경)의 총 15 건임.

ㅁ 이 중 12 개 사업이 현재 종료된 상태이며, 3 개 사업이 진행 중으로 현재 진행 중인 사업 중 2 개는 2010년, 1개는 2012년에 각각 종료될 예정임.

\section{적절성}

ㅁ 평가대상 사업이 전반적으로 $\mathrm{CAS}$ 와의 연계성 및 적절성이 높은 것으로 나타남.

○ CAS가 '07년 외교통상부 주도 하에 KOICA와 공동 수립시, '07년 이전에 이미 이집트에 중점 적으로 지원된 사업을 CAS에 반영하였기 때문임.

ㅁ 평가대상 사업은 또한 수원국인 이집트의 “미래비전(2030)” 및 “제6차 5개년 계획(2007/8년 $2011 / 12$ 년)”과 같은 주요 개발정책 방향 및 개발수요와의 적절성이 높은 것으로 평가됨.

○ 특히, “자동차 정비 직업훈련원 지원 사업”, “문화재청 유물정보시스템 구축사업” 및 "배전자 동화시스템 구축사업 “은 이집트 정부의 주요한 개발과제에 대응하는 사업으로 평가받고 있음. 
ㅁ 평가대상 사업의 목적 및 목표달성 여부와 관련해서는 종료보고서, 설문 및 현지 면담조사 결과 전반적으로 만족스러운 것으로 평가되었음.

ㅁ 평가대상 사업은 다양한 분야에서 이집트에 기여하였으며, 주된 기여분야로는 '경제적 편익 창출 및 소득증대' 및 '기술 및 관리역량 배양'이 높은 평가를 받았음.

○ 이에 반해, '정책 및 제도개선' 및 '사회적 복지 증대'에 대한 기여는 상대적으로 빈약한 것으로 나타났으며, 이는 KOICA의 사업이 중앙정부를 대상으로 한 제도 개선 및 역량구축에 초점을 맞춘 사업이 아니라 직접적으로 빈곤층의 소득증대를 지원하는 사업 결과로 판단됨.

ㅁ 수원기관에 대한 인터뷰 및 설문결과, 전반적으로 평가대상 사업에 대한 만족도는 높은 것으로 나 타났음.

○ 그 요인으로 수요에 적합한 체계적인 사업계획, 양측간 합의된 종료일자 및 세부사항에 따른 체 계적인 사업실행, 사업종료 후의 사후사업 실행, 주기적인 사업평가 및 모니터링, 적절한 재정 지원, 고급기술 지식의 이전, 시간과 노력의 단축 및 정확도 향상 등을 들었음.

만편, $\mathrm{KOICA}$ 사업담당자 및 $\mathrm{PMC}$ 기관 담당자의 면담에서는 다음과 같은 문제점 및 애로사항이 나타났음.

○ KOICA 사업수 대비 사업추진 인력 부족.

○ 한국과의 이질적 문화적 차이(이슬람 문화권), 생활양식의 차이(퇴근시간이 오후 3시) 및 직장 조직체계의 차이(관리자급에 책임 집중)로 인한 사업의 순조로운 진행의 어려움.

○ 이집트의 젊은 기술인력이 적재적소에 배치되지 못하고 있으며, IT 기술력에 비해 관련 인프라 (PC 등)가 충분히 제공되지 못함.

\section{효율성}

$\mathrm{KOICA}$ 의 대 이집트 지원사업에 대한 전반적인 효율성은 상당히 높은 것으로 평가되었으며, 세부 사업구성, 투입요소, 예산 및 투입기간 등에 대하여 적절하다는 의견이 많았음.

○ 특히 4건의 "자동차 정비 직업훈련원 지원 사업“의 경우 체계적이고 집중적인 지원으로 수혜 기관들의 인적자원개발 역량을 배양하고 제도변화를 촉진한 점은 다른 프로젝트에 비해 비용 효율성이 매우 높은 사업으로 평가됨.

$\mathrm{KOICA}$ 및 한국 측 사업수행기관의 전반적인 역량에 대해서는 만족도가 높았으나, 공통적으로 사 회문화적인 차이로 인하여 파견전문가와 현지인간의 의사소통이 원활하게 이루지지 않는 것에 대 해서 이슈를 제기하였음.

○ 이와 관련하여 현지인을 통역으로 활용하는 방안을 적극 고려하고, 이와 더불어 한국에서 전문 가를 파견하기 전에 현재보다 철저한 사전 교육이 필요할 것으로 보임. 


\section{파급효과}

ㅁ 정책 및 제도개선과 관련, 자동차 정비 직업훈련원의 경우만 제외하고 평가대상 사업 모두 파급효 과가 높은 것으로 평가되었음.

○ “자동차 정비 직업훈련원 지원 사업”의 경우에 사업을 관리하는 직업훈련청은 해당 분야에 대한 파급효과가 매우 높다고 평가한 반면, 직업훈련원 측의 평가는 다소 저조한 것으로 나타났음.

○ 이와 같은 상반된 평가결과는 정책 및 제도개선과 같은 소프트웨어 측면이 주로 상위기관에서 결정 - 추진되며, 실제 사업장에서는 시설, 장비와 같은 하드웨어 측면에 대한 보완 및 개선이 이루어지기 때문인 것으로 추측됨.

ㅁ 지역사회개발과 관련하여 "배전자동화 시스템 구축"과 같은 산업에너지 분야 사업의 경우, 대상 지역의 인프라 개선을 바탕으로 지역사회 발전 및 경제 활성화에 초점을 맞추고 있으며, 이에 따 라 본 사업의 확대를 통한 해당 지역사회의 개발에 긍정적인 영향을 미칠 것으로 기대됨.

ㅁ 평가대상 사업은 수원국의 사회적 결속 및 윤리문화적 행태와 관련하여 다소 긍정적인 영향을 미 친 것으로 평가되었으며, 설문 응답자 및 인터뷰 대상자 전원이 $\mathrm{KOICA}$ 사업을 통하여 양국 간 우호관계가 강화되었고 한국의 이미지와 인상에 대한 영향도 매우 긍정적이라고 답변하였음.

\section{지속가능성}

ㅁ 설문조사에서 평가대상 사업의 재무적 지속가능성이 높을 것이라 평가되었으나 인터뷰에서는 우 려가 될 수 있는 부분으로 나타났음.

ㅁ “배전자동화 시스템 구축사업”의 경우를 살펴보면, 향후 고장이 나거나 노후화된 부품의 자체조 달에 대해 우려를 표하고 있으며, 이에 대한 해결책으로는 KOICA 사업예산 구성 시 일정 정도의 사후관리 예산을 편성하는 것을 고려할 수 있을 것임.

ㅁ 그러나 무엇보다도 수원국의 주인의식, 재정적 지원, 자체예산 조달 방안 강구 등이 선행되어야 할 것임.

\section{성주류화 및 환경에 대한 고려}

$\mathrm{KOICA}$ 사업의 형성 및 집행 단계에서 여성을 별도로 고려하지 않았으며, 이에 대한 주된 이유로 는 대부분의 프로젝트/개발조사 사업이 성주류화의 고려 필요성이 크지 않았던 것에 기인한 것으 로 보임.

ㅁ 평가 대상 개발조사 사업은 대부분 해당 가이드라인의 마련 이전에 사업이 형성되었음에도 환경영 향에 대한 조사를 비교적 충실히 하고 있는 것으로 파악되었음.

ㅁ 그럼에도 불구하고, 설문조사 결과, 프로젝트 실행시 환경보호에 대한 활동 여부에 대하여 대부분 의 응답자가 전혀 없었던 것으로 나타남. 
○ 이와 관련하여, 자동차의 경우에 배출되는 유해물을 한국에서는 어떻게 처리하는지에 대한 교 육과정과 직장인의 건강과 안전에 대한 훈련과정의 신설을 제안하였음.

○ 그러나 자동차 유해물 처리에 대한 내용이 "자동차 직업훈련 시스템 개선사업 "내의 교재개발 사업에 포함되어 향후 $\mathrm{KOICA}$ 지원의 전체 자동차 정비 직업훈련원 교육과정에 포함될 것으로 파악되었음.

\section{2) 국내초청연수 사업}

ㅁ '91 '09년 총 640명을 초청, 304개 연수과정 실시.

ㅁ '09년의 지원액은 초기 지원규모의 70배에 달하는 등 규모가 지속적으로 확대.

ㅁ 지원 분야는 행정제도 분야에서의 지원이 두드러진 것으로 나타나고 있으며, 국별, 공동, 학위 연 수 등으로 연수 유형이 다양화되었음.

○ 매년 행정제도 분야의 국별 연수가 빠짐없이 실시된 것으로 나타남.

\section{적절성}

$\mathrm{KOICA}$ 의 원조지원 목표 중 '인적자원개발을 통한 경제성장'에 가장 크게 기여한 것으로 평가되었 으며, 4 대 중점지원 분야에서는 행정제도, 산업에너지, 정보통신, 환경분야 순으로 지원이 제공되 었음.

\section{효과성}

ㅁ 전문지식 공유와 상호이해의 폭을 넓히는데 가장 효과적인 것으로 평가되었으며, 행정발전, 공공 분야의 기초 인적자원개발 및 역량강화 측면에서도 높은 성과를 보인 것으로 나타남.

\section{효율성}

ㅁ 국내초청연수 사업에 대한 효율성은 높은 것으로 평가되었으나, 이집트 측에서 2 3주의 단기 연 수는 심층적인 전문지식의 학습이 곤란하므로 장기 연수 프로그램 및 학위연수 프로그램의 확대 를 요청.

ㅁ 장기 프로그램 확대에 소요되는 물리적인 비용과 시간문제를 극복하기 위한 대안으로 현지연수 및 제3국 연수를 고려할 수 있음.

○ 현지에서 필요한 업무에 대해 핵심기술과 지식을 가진 국내전문가를 신속히 파견, 심층적인 연 수를 함으로서 효율적으로 실무능력을 향상시킬 수 있기 때문임.

○ 또한 이는 수원국의 공동주최국으로서의 적극적 지원과 협조가 바탕이 되었을 때 그 효과성이 
보장될 것임.

ㅁ 연수 수요발굴 및 평가체계와 관련하여 $\mathrm{KOICA}$ 는 최근 중 - 장기적인 관점에서 연계성 있는 연수 사업을 연차적으로 추진하기 위한 노력을 보이고 있음.

○ 이집트에서는 산업 - 에너지 분야의 다년간(3년) 국별연수를 위해 외교부와 이집트 KOICA 사무 소 간에 협의를 가졌음.

○ 이처럼 현지 KOICA 사무소의 신규사업 발굴에 대한 역할이 확대되는 것은 수원국의 특수한 수 요와 우리의 비교우위를 더욱 적극적으로 반영할 수 있는 계기를 마련할 것으로 기대됨.

ㅁ이집트 공무원행정발전'과 같이 이미 5년째 실시 중인 다년간의 사업은 프로그램 진행 노하우 축 적과 수원국의 이해제고로 성과가 높음.

\section{파급효과 및 지속가능성}

ㅁ 이집트 연수사업의 영향력은 매우 긍정적으로 평가되었으나 개발원조가 아니라 인적교류의 접근 방식과 창구를 활용하고 있으므로 프로그램 개발이 비교적 주관적이고 임의적일 수 있음.

$\mathrm{KOICA}$ 내 여타 프로젝트 팀과의 정규적인 논의창구 없이 독자적으로 기획, 실시되고 있어 그 영 향력과 지속가능성이 단발성으로 끝날 가능성이 큼.

○ 이는 $\mathrm{KOICA}$ 가 지역적 편제로 재구성되는 과정에서 해결되어야 하는 사항임.

\section{성주류화 및 환경에 대한 고려}

ㅁ 최근 5 년간 $\mathrm{KOICA}$ 의 마커 현황을 살펴보면, 여성 및 환경 모두 해당분야를 위한 노력이 증대되 고 있음을 알 수 있음 .

ㅁ 최근 4년간 여성 연수 참여비율은 가이드라인 권고 여성선발율의 $30 \%$ 를 초과 달성하였음.

ㅁ 최근 종합적인 녹색성장 개발역량강화('07 '08년 환경친화적 에너지 개발전문가 능력배양)를 위 한 노력을 보이고 있음.

\section{3) 해외봉사단파견 사업}

ㅁ 1998년 첫 봉사단원 4명의 파견을 시작으로 '09년까지 총 274 명이 보건의료, 산업에너지(직업훈 련), 정보통신 순으로 파견됨.

\section{적절성}

$\mathrm{KOICA}$ 의 $\mathrm{CAS}$ 중 기초서비스 확대 및 인적자원개발, 이집트 국가개발비전의 인적자원개발을 통 한 고용증대 및 사회 서비스 증진 부분에 기여하고 있음. 
ㅁ 이집트 내 최대 규모의 봉사단 사업, 현지주민의 삶의 질 개선, 한-이 양국협력 및 우호관계 수립 에 매우 비중 있는 역할을 하고 있으며 보건의료와 정보통신 분야에서의 성과가 높이 평가되었음.

ㅁ 이집트 KOICA 해외봉사단 사업 국별전략(2010 2013년)이 최근 수립되어 분야별, 지역별, 사업 규모 관련 지원전략 및 평가방안에 대한 구체적인 가이드라인이 제시되었음.

O $\mathrm{KOICA}$ 의 대 이집트 $\mathrm{CAS}$ 틀 안에서 기타 사업과 일관성 있게 수행될 수 있는 여건과 체계를 마련하였으나, 다만 주요 분야별 지원 증감계획에 대한 논리적 검토과정이 제시되어 있지 않아 추가 정보제공이 필요함.

ㅁ 주니어 전문가로서 전문성 및 실무경험의 한계로 인하여 활동기관에서 요구하는 충분한 수준의 전 문성을 발휘하지 못하는 경우가 일부 발견되었음.

\section{효율성}

ㅁ 전반적으로 적절하다는 평가를 받았으나 수원국 봉사단 총괄기관인 외교부에서는 효과성을 보다 제고할 개선점으로 봉사단원의 현지어 구사능력을 제안하였음.

○ 봉사단원에 대한 추가 언어교육 실시는 $\mathrm{KOICA}$ 의 현지 훈련체제 전환 노력과 병행하여 추진할 필요가 있음.

\section{파급효과 및 지속가능성}

뭍철한 사명감과 뛰어난 자질로 이집트 지역사회의 복지와 양국간 우호관계 형성에 장기간동안 큰 영향을 끼친 봉사단원들의 사례가 많이 발견되었음.

ㅁ 기존 이집트 봉사단 관리인력이 일인당 33 명에서 25 명으로 감소하였으며, 이는 단순한 파견인원 실적 달성이 아닌 실질적인 효과 창출과 봉사활동의 뚜렷한 목표의식을 위한 노력의 반영이라 할 수 있음.

\section{성주류화 및 환경에 대한 고려}

ㅁ 보건의료(간호) 및 산업에너지(봉제) 부분에서 모자보건과 여성의 경제능력 향상 등을 통한 성 주 류화 노력의 확대 추세가 보이며, 향후에도 지향할 필요가 있음.

ㅁ 봉사단 파견을 통한 환경분야 지원은 다소 미흡하며, 부재하거나 한명정도의 환경청 파견이 환경 에 대한 고려를 반영하고 있는 실정임.

○ 이는 환경분야에 요구되는 기술적 전문성으로 인한 주니어 봉사단원 파견의 어려움이 다소 반 영된 결과이고, 팀제봉사단 혹은 시니어 봉사단원의 활용이 기대되는 부분임. 


\section{N. 결론 및 건의}

\section{1) 대 이집트 개발협력의 새로운 방향}

ㅁ (대 이집트 개발협력의 새로운 방향 모색) 이집트의 대내외적 개발 환경이 크게 변화하고 있는 점 등을 감안하여 향후 이집트에 대한 개발협력의 방향과 전략을 중 - 장기적인 관점에서 새롭게 수 립할 필요가 있음.

ㅁ (개발협력 지원의 지속성 확보) 이집트가 지난 20년 동안 무상원조사업의 중점협력 대상국으로 자 리해왔던 사실과 양국 간의 다면적인 관계에 미치는 영향 등을 고려하여 이집트에 대한 개발원조 는 지원의 지속성 확보라는 차원에서 신중하게 검토될 필요가 있음.

○ 이집트에 대한 원조 사업의 효과 및 효율성 등이 큰 것으로 나타났을 뿐만 아니라 우리의 원조 제공에 대한 수요와 기대가 큰 만큼 당분간 대 이집트 원조를 현상 이상의 수준으로 유지해나가 면서 이집트의 경제적 수준향상 등을 고려하여 중기적인 관점에서 원조 출구 전략을 마련하는 것이 바람직하다고 봄.

ㅁ (대 이집트 원조 지원 중점의 명확화) 2011년까지의 CAS가 마무리되는 시점에서 CAS에 대한 새 로운 방향 모색이 요구됨.

○ 2012년 이후에 실천할 KOICA의 새로운 CAS 수립에 있어서는 이집트의 "카이로 행동 계획 (CAA)"에 일치되는 방향에서 보다 뚜렷한 대 이집트 원조의 중점과 전략적 지원 분야를 설정 하는 것이 바람직함.

ㅁ (향후 원조 추진 중점) 이집트의 경제적 지위가 중저소득국의 수준으로 향상된 점 등을 고려하여 향후의 원조 목표는 그 간 지원 중점을 두어온 인적자원개발 지원 등 성장의 촉진을 통한 지속가 능 발전을 도모하는 목표에 보다 집중하는 것이 바람직함.

○ 새롭게 설정될 대 이집트 무상원조 정책에 입각하여 원조의 목표 및 지원중점 분야를 선정하되 아래와 같은 대안을 제시할 수 있음.

(1) 당분간 현 수준의 지원을 실시하는 경우에는 그 간에 큰 성과를 거두었던 인적자원개발, ICT 분야 지원 지속.

(2) 지원 규모를 확대하는 경우 이집트가 성장 동력의 육성 대상으로 선정한 7개 전략 분야 중에서 1 개 분야를 선정하여 전략적으로 지원.

(3) 당장 출구 전략 단계로 진입하여 지원 규모를 단계적으로 축소하는 경우, 기존에 착수된 사업 을 완공 위주로 추진하면서 이집트가 개발 역량의 확충에 가장 큰 애로 요인으로 들고 있는 정 부 행정 - 제도적 역량의 부족을 지원할 수 있는 연수생초청 사업과 인적교류 협력을 지속시켜 나갈 수 있는 봉사단파견 사업을 지속적으로 추진. 
ㅁ (유기적인 원조 접근 및 사업 추진) 여러 개발협력 수단이 특정 부분 지원 또는 과제 해결을 위한 부문 접근 내지는 프로그램 접근 방식을 통하여 효과적으로 전개될 수 있는 원조 실시 기법을 발 전시켜 나감.

○ 주요한 무상원조사업 수단들을 유기적으로 연계 조화시켜 사업 추진의 시너지 효과를 도모함.

\section{2) 실천적인 대 이집트 국가지원전략의 수립}

ㅁ (유용성을 갖춘 CAS의 마련) 2010/2011년 이후의 차기를 목표로 마련될 CAS는 유도적인 원조 방향의 제시로부터 이집트가 현재 진행하고 있는 "카이로 행동계획(CAA)"의 마련을 위한 상황 분석(Situation Analysis) 등 일련의 검토 작업을 바탕으로 보다 실천적인 전략을 마련함.

○ 개발 과제의 선정에 대한 보다 논리적인 접근은 물론 성과 지향의 사업추진을 도모할 수 있는 '전략적 협력의 틀(Strategic Framework)'을 수립함.

○ 구체적인 개발 및 성과 지표를 명확하게 제시함.

ㅁ 예측가능성과 실천성을 갖춘 시행 관리 프로그램을 수립함.

○ 새로운 $\mathrm{CAS}$ 에는 주요 사업 내용, 연도별 재원투입 계획 등의 국가지원전략 이행 계획을 포함함.

\section{3) 원조 실시 프로세스 개선 방안}

ㅁ (이집트 등 국가 지원에 초점을 두는 원조 실시 체제 구축) $\mathrm{KOICA}$ 의 사업지원 체제 및 국가지원 전략 수립과 시행 프로세스를 이집트 등 국가 지원에 초점을 두는 방향으로 개선함.

○ 이집트 국가지원전략 $\rightarrow$ 이집트 연간사업계획 $\rightarrow$ 협력사업 실시의 기본 시스템 구축.

ㅁ (CAS에 바탕을 두는 사업 추진 프로세스 구축) 3 5년 내외의 기간을 목표로 하여 수립되는 $\mathrm{CAS}$ 를 바탕으로 연간 사업계획을 수립하여 시행하고 이를 평가 · 환류시켜 원조사업의 실시를 체계화 하는 기본적인 프로세스를 구축하여 운영함.

$\circ \mathrm{CAS}$ 수립 $\rightarrow$ 원조계획 수립 $\rightarrow$ 원조사업 실행 $\rightarrow$ 평가 $\rightarrow$ 환류 $\rightarrow$ 원조정책 대화 $\rightarrow$ 새로운 $\mathrm{CAS}$ 수립 · 시행.

ㅁ (원조 실시 프로세스 개선) 원조효과 및 효율성 제고를 위하여 프로젝트사업의 경우, 사업발굴 등 정보공유를 위한 타 공여국과 협의활동 활성화, 수요조사 및 사전타당성 조사 운용 관리 개선, 프 로젝트사업 추진시 $\mathrm{PDM}$ 수립 의무화 및 사업평가 실시 강화 등이 필요함.

○ 연수생초청사업의 경우, 현지 사무소의 연수생 선발 심사 강화 및 2 주 미만 등 단기 연수 프로 그램의 연수기간 조정과 봉사단파견 사업의 경우에는 봉사단 자원 확보를 위한 홍보 활성화 및

현지어 습득을 위한 교육훈련 강화 등의 개선이 필요함.

ㅁ (원조 지원방식 등 개선) 원조의 시너지 효과 제고를 위하여 $\mathrm{KOICA}$ 무상원조 사업간의 연계성 제 도 확보 및 원조실시 기법 및 방법론에 대한 선진개발 시스템 구축을 위한 방안 마련이 필요함. 
○ 정책연구실 기능 강화 및 현장중심 체제를 위한 현지사무소 인력 보강과 더불어 KOICA 본부사 업의 소프트웨어 부문 아웃소싱 확대 등 원조 지원방식의 적절한 개선이 필요함.

\section{4) 원조 성과 향상 및 효과 제고 방안}

ㅁ (체계적인 사업 실시 접근) 본 사업 추진에 앞서 해당 사업 추진과 관련한 기초적인 조사 및 사전 검토, 협의 작업이 보다 심층적으로 이루어질 필요가 있음.

ㅁ (사업의 효과성을 위한 차별화 전략 채택) “자동차 정비 직업훈련원 지원 사업”의 경우에 본 사업 추진에 앞서 지역특성에 관한 기초적인 조사 및 사전 검토를 통해 각 지역의 특성에 맞도록 교육 훈련 시설 수준을 차별화 할 필요성이 있음.

○ 모든 지역에 동일한 높은 수준의 교육훈련 시설을 제공하는 것은 비용효과적이지 않을 뿐만이 아니라 졸업 후 그 지역에서 취업을 해야 하는 훈련원 졸업생의 입장에서도 바람직하지 않음.

ㅁ (수원국의 목표 및 주인의식이 확고한 사업 개발 및 참여) 향후 국별 지원사업의 추진에 앞서 수원 국의 목표 및 주인의식이 확고한 부문에 집중하여 사업 개발 및 참여할 필요가 있음.

ㅁ (사업의 지속가능성에 대한 고려 중시) 지속가능성 확보를 위한 방안이 사업 실시 계획 및 시행계 획 디자인 단계에서 미리 면밀하게 고려되는 것이 바람직함.

○ “자동차 정비 직업훈련원 지원 사업”의 경우, 사업지속가능성 제고를 위하여 추진되고 있는 비 즈니스 모델 수립 사업은 매우 유용한 방안으로 평가됨.

ㅁ (계획적인 사후 관리 강화) 일정 시점이 경과된 완료 사업을 대상으로 사업 운영 전반에 대한 점검 과 사후 지원 요소를 종합적으로 진단 평가하고 사후 조치를 건의하는 사후관리 전문기술단의 파 견은 효과가 매우 클 것으로 기대됨. 